\title{
Ultrasound-targeted microbubble destruction-mediated Foxp3 knockdown may suppress the tumor growth of HCC mice by relieving immunosuppressive Tregs function
}

\author{
CHUNYING SHI $^{1}$, YU ZHANG ${ }^{1}$, HAICHAO YANG ${ }^{1}$, TIANXIU DONG ${ }^{1}$, \\ YAODONG CHEN $^{1}$, YUTONG XU ${ }^{1}$, XIUHUA YANG ${ }^{1}$ and PENGFEI LIU ${ }^{2}$ \\ ${ }^{1}$ Department of Abdominal Ultrasound; ${ }^{2}$ MRI Department, \\ The First Affiliated Hospital of Harbin Medical University, Heilongjiang, Harbin 150001, P.R. China
}

Received October 14, 2015; Accepted April 10, 2017

DOI: $10.3892 / \mathrm{etm} .2017 .5421$

\begin{abstract}
The aim of the present study was to investigate the effect of Forkhead family transcription factor P3 (Foxp3) knockdown on the function of cluster of differentiation $(\mathrm{CD}) 4^{+} \mathrm{CD} 25^{+}$regulatory $\mathrm{T}$ cell (Tregs) and the tumor growth of a hepatocellular carcinoma (HCC) mouse model. $\mathrm{CD} 4^{+} \mathrm{CD} 25^{+}$Tregs and $\mathrm{CD} 4^{+} \mathrm{CD} 25^{-} \mathrm{T}$ cells were sorted from peripheral blood mononuclear cells (PBMCs) of patients with HCC. Then, ultrasound-targeted microbubble destruction (UTMD)-mediated Foxp3-microRNA (miRNA) was transfected into Tregs. Subsequently, CD $4^{+} \mathrm{CD} 25^{-} \mathrm{T}$ cells were co-cultured with PBMC and Tregs without Foxp3-miRNA (Foxp3 ${ }^{+}$Tregs) or Tregs with Foxp3-miRNA (Foxp3 Tregs) and the proliferation-inhibition ratio of $\mathrm{CD} 4{ }^{+} \mathrm{CD} 25^{-} \mathrm{T}$ cells was detected using a Cell Counting Kit-8. Additionally, HCC mice were treated with UTMD-mediated Foxp3-shRNA, the tumor volume was calculated and the content of $\mathrm{CD}^{+}$and $\mathrm{CD} 25^{+}$ $\mathrm{T}$ cells in the blood were detected using flow cytometry. The content of interferon- $\gamma$ (IFN- $\gamma$ ), interleukin (IL)-2, IL-10, transforming growth factor- $\beta$ (TGF- $\beta$ ) and vascular endothelial growth factor (VEGF) in cultural supernatant and serum were detected by ELISA analysis. Foxp3 Tregs significantly reduced the inhibition effect of Foxp $3^{+}$Tregs on the proliferation of $\mathrm{CD} 4^{+} \mathrm{CD} 25^{-} \mathrm{T}$ cells $(\mathrm{P}<0.01)$. The content of IFN- $\gamma$ and
\end{abstract}

Correspondence to: Dr Xiuhua Yang, Department of Abdominal Ultrasound, The First Affiliated Hospital of Harbin Medical University, 23 Youzheng Street, Heilongjiang, Harbin 150001, P.R. China

E-mail: xiuhuayang159@hotmail.com

Dr Pengfei Liu, MRI Department, The First Affiliated Hospital of Harbin Medical University, 23 Youzheng Street, Heilongjiang, Harbin 150001, P.R. China

E-mail: lpflpfmri@sina.com

Key words: ultrasound-targeted microbubble destruction, forkhead family transcription factor P3, cluster of differentiation $4^{+}$cluster of differentiation $25^{+}$regulatory $\mathrm{T}$ cells, regulatory $\mathrm{T}$ cells
IL-2 significantly increased, while IL-10 and TGF- $\beta$ significantly decreased in the co-cultured system of Foxp3Tregs compared with the co-cultured system of Foxp $3^{+}$Tregs $(\mathrm{P}<0.01)$. Following treatment with Foxp3-shRNA, the average tumor volume, ratio of Tregs/CD4 ${ }^{+} \mathrm{T}$ cells and level of IL-10, TGF- $\beta$ and VEGF significantly decreased, however, the level of IFN- $\gamma$ and IL-2 significantly increased compared with un-treated HCC mice $(\mathrm{P}<0.05)$. Foxp3 knockdown may suppress the tumor growth of $\mathrm{HCC}$ mice through relieving the immunosuppressive function of Tregs.

\section{Introduction}

Hepatocellular carcinoma (HCC) is one of the most challenging malignant tumors, with a high morbidity and mortality in China $(1,2)$. Although progress has been made in surgery (transplant, embolization or resection); radiation therapy, chemotherapy and ablation, tumor recurrence and metastasis remain difficult to treat (3). Therefore, investigations into the molecular mechanism of recurrence and metastasis of HCC, and less invasive but more effective therapeutic methods for clinical HCC treatment are required.

Immunotherapy has been applied in the treatment of HCC in early clinical trials due to its characteristics: Systemic, nontoxic and long-lived anti-tumor activity (4). Previous studies have demonstrated that the tumor microenvironment may be established by the regulation of lymphocytes, and then serves a vital role in the progression of tumors through immunity and inflammation $(5,6)$. It is well known that cluster of differentiation (CD) $4^{+} \mathrm{CD} 25^{+}$regulatory $\mathrm{T}$ cells (Tregs) contribute to the growth of malignant tumors through suppressing immune surveillance (7). Forkhead family transcription factor P3 (Foxp3) is specifically expressed in Tregs and serves an important role in the negative immunoregulatory function of Tregs in mice and humans $(8,9)$. A previous study has indicated that in murine tumor models, downregulated Foxp3 inhibits the tumor growth of $\mathrm{CD} 4{ }^{+} \mathrm{CD} 25^{+}$Tregs, as observed in leukemia (10). Other studies have demonstrated an increased expression of $\mathrm{CD} 4{ }^{+} \mathrm{CD} 25^{+}$Tregs in patients with HCC $(11,12)$. However, the effects of a Foxp3 knockdown on the function of $\mathrm{CD}^{+} \mathrm{CD} 25^{+}$ Tregs and the development of HCC remain to be elucidated. 
Currently, the application of ultrasound-targeted microbubble destruction (UTMD) for gene delivery has become a focus of research due to its low immunogenic, non-invasive, targeted and high-efficiency characteristics $(13,14)$. UTMD has been demonstrated to efficiently deliver genes to cells, myocardium and solid tumors (15-17). In the present study, the expression of Foxp3 was downregulated through UTMD-mediated delivery of Foxp3-microRNA (miRNA) and Foxp3-short hairpin RNA (shRNA) in $\mathrm{CD}^{+} \mathrm{CD} 25^{+}$Tregs to a HCC mice model, respectively. Whether Foxp3 knockdown was able to inhibit the negatively immunoregulatory function of $\mathrm{CD}^{+}{ }^{+} \mathrm{CD} 25^{+}$Tregs and suppress the tumor growth of $\mathrm{HCC}$ through improving the immune microenvironment was then assessed.

\section{Materials and methods}

Patients. The current study recruited a total of 50 patients (28-76 years; male/female, 41/9; 63.77-83.25 kg) with HCC at The First Affiliated Hospital of Harbin Medical University (Harbin, China) from October 2013 to May 2014. The inclusion criteria were as follows: i) All patients were newly diagnosed with TNM stage I-II cancer (18) and did not accept any treatment; ii) patients had no other organic disease with the exception of hepatic pathological changes; and iii) patients had elevated levels of alphafetoprotein and aminotransferase (diagnostic indicators for hepatocellular carcinoma). Approval from the Ethics Committee of The First Affiliated Hospital of Harbin Medical University was obtained and written informed consent was received from all patients.

Separation of peripheral blood mononuclear cells, CD4 ${ }^{+}$ $C D 25^{+}$Tregs and $C D 4^{+} C D 25^{-} T$ cells. Initially, venous blood (40-60 ml) was collected aseptically from patients with HCC, and diluted with the same volume of phosphate buffered saline. The diluted blood samples were slowly added on the liquid surface of lymphocyte isolation medium (Shaanxi Haoyang Biological Technology Co., Ltd., Xi'an, China) at a ratio of 1:1, and peripheral blood mononuclear cells (PBMCs) were separated by centrifugation $(700 \mathrm{x}$ g for $25 \mathrm{~min}$ at $25^{\circ} \mathrm{C}$ ). Subsequently, $\mathrm{CD} 4^{+} \mathrm{CD} 25^{+}$Tregs and $\mathrm{CD} 4^{+} \mathrm{CD} 25^{-} \mathrm{T}$ cells were sorted from PBMCs using $\mathrm{CD} 4{ }^{+} \mathrm{CD} 25^{+}$Tregs magnetic bead separation kit (Miltenyi Biotec $\mathrm{GmbH}$, Bergisch Gladbach, Germany) following the manufacturer's protocol. The sorted $\mathrm{CD} 4{ }^{+} \mathrm{CD} 25^{+}$Tregs or $\mathrm{CD} 4{ }^{+} \mathrm{CD} 25^{-} \mathrm{T}$ cells $\left(1 \times 10^{7} / \mathrm{ml}, 0.1 \mathrm{ml}\right)$ were co-stained with anti-CD4 fluorescein isothiocyanate (FITC)-conjugated and anti-CD25 phycoerythrin (PE)-conjugated antibodies $(10 \mu \mathrm{g} / \mathrm{ml}$; cat. nos. 555346 and 555432; BD Biosciences, Franklin Lakes, NJ, USA) for 30-40 min at room temperature away from light. Cells were washed with PBS, and samples were fixed in $1 \%$ formaldehyde solution at $4^{\circ} \mathrm{C}$ for $1 \mathrm{~h}$ and detected by FACSCria (BD Biosciences). Finally, the data were analyzed by FACSDiva software (version 4.1; BD Biosciences), and the purity of the $\mathrm{CD} 4{ }^{+} \mathrm{CD} 25^{+}$Tregs and $\mathrm{CD} 4{ }^{+} \mathrm{CD} 25$ $\mathrm{T}$ cells was detected at $>90 \%$.

Construction of Foxp3-miRNA and Foxp3-shRNA expression plasmids. A specific miRNA sequence targeted to human Foxp3 (GenBank Accession No. NM_50943; https:// www.ncbi.nlm.nih.gov/gene/?term=50943) and a control miRNA sequence (Table I) were designed and chemically synthesized by Invitrogen (Thermo Fisher Scientific, Inc., Waltham, MA, USA). Double-stranded DNA oligonucleotides corresponding to miRNA were obtained by the annealing of two corresponding oligomeric single-strand DNA at $95^{\circ} \mathrm{C}$ for $5 \mathrm{~min}$ and inserted into pcDNA6.2-GW/EmGFP-miR vector (Invitrogen; Thermo Fisher Scientific, Inc.). A specific shRNA sequence targeted to mouse Foxp3 (Table I) was designed by Shanghai GenePharma Co., Ltd. (Shanghai, China) and cloned into the pGPU6/GFP/Neo vector (Invitrogen; Thermo Fisher Scientific, Inc.). Ultimately, the recombinant plasmid Foxp3-miRNA and Foxp3-shRNA were successfully constructed.

Preparation of microbubble. SonoVue powder (Bracco, Milan, Italy) was dissolved in $5 \mathrm{ml}$ normal saline. Following 5 min oscillation, microbubbles were evenly distributed. Microbubbles with a density of $2 \times 10^{8}-5 \times 10^{8} / \mathrm{ml}$, diameter of 2.5-6.0 $\mu \mathrm{m}$ and concentration of $5 \mathrm{mg} / \mathrm{ml}$ were observed under a light microscope (Olympus Corporation, Tokyo, Japan).

Cell transfection and grouping. Tregs with a concentration of $1 \times 10^{6} / \mathrm{ml}$ were resuspended in serum-free RPMI-1640 medium (Gibco; Thermo Fisher Scientific, Inc.), and $1.5-2 \times 10^{5}$ cells were seeded into each well of a 96-well plate (Corning Incorporated, Corning, NY, USA). Then, the cells were divided into 7 groups as follows: i) Control group, $90 \mu \mathrm{l}$ medium $+10 \mu \mathrm{l}$ control plasmid; ii) SonoVue microbubbles + Foxp3-miRNA plasmid $(\mathrm{MB}+\mathrm{P})$ group, $80 \mu 1$ medium $+20 \mu 1$ mixture of microbubbles and Foxp3-miRNA plasmid (1:1); iii) ultrasound + Foxp3-miRNA plasmid $(\mathrm{US}+\mathrm{P})$ group, $90 \mu \mathrm{l}$ medium $+10 \mu 1$ Foxp3-miRNA plasmid with ultrasonic irradiation; iv) ultrasound + SonoVue microbubbles + Foxp3-miRNA plasmid (US $+\mathrm{MB}+\mathrm{P}$ ) group, $80 \mu 1$ medium $+20 \mu \mathrm{l}$ mixture of microbubbles and Foxp3-miRNA plasmid (1:1) with ultrasonic irradiation; v) Lipofectamine ${ }^{\circledR} 2000$ (Invitrogen; Thermo Fisher Scientific, Inc.) + Foxp3-miRNA plasmid $(\mathrm{L}+\mathrm{P})$ group, $90 \mu 1$ medium $+10 \mu 1$ Foxp3-miRNA plasmid $+1 \mu$ l Lipofectamine ${ }^{\circledR} 2000$; vi) Ul trasound + Lipofectamine2000 + Foxp3-miRNA plasmid $(\mathrm{US}+\mathrm{L}+\mathrm{P}$ ) group, $90 \mu 1$ medium $+10 \mu 1$ Foxp3-miRNA plasmid $+1 \mu$ l Lipofectamine2000 with ultrasonic irradiation; vii) Ultrasound + SonoVue microbubbles + Lipofectamine $2000+$ Foxp3-miRNA plasmid ( US + MB + L + P) group, $80 \mu 1$ medium $+20 \mu 1$ mixture of microbubbles and Foxp3-miRNA plasmid (1:1) $+1 \mu 1$ Lipofectamine ${ }^{\circledR} 2000$ with ultrasonic irradiation. The groups with ultrasonic irradiation were exposed to irradiation conditions with (MI=1.4; exposure time $=150 \mathrm{sec}$ ) using IU22 ultrasonic equipment (Philips Healthcare, DA Best, The Netherlands). Following transfection for $24 \mathrm{~h}$, the transfection efficiency was observed under fluorescence microscope (Olympus Corporation) and detected by FACSCalibur flow cytometer (BD Biosciences) as previously described (19). Results were analyzed using FACSComp (version5.1) software (BD Biosciences).

Detection of Tregs activity. Following $24 \mathrm{~h}$ transfection, $10 \mu \mathrm{l}$ Cell Counting Kit (CCK)8 (Dojindo Molecular Technologies, Inc., Kumamoto, Japan) was added into each well and cultured 
Table I. miRNA and shRNA sequences of Foxp3.

RNA type

Sequence $\left(5^{\prime}-3^{\prime}\right)$

miRNA-Foxp3

F: TGCTGCACAGATGAAGCCTTGGTCAGGTTTTGGCCACTGACTGACCTGACCAAC TTCATCTGTG

R: CCTGCACAGATGAAGTTGGTCAGGTCAGTCAGTGGCCAAAACCTGACCAAG GCTTCATCTGTGC

miRNA-Foxp3-NC

F: TGCTGAAATGTACTGCGCGTGGAGACGTTTTGGCCACTGACTGACGTCTCCA CGCAGTACATTT

R:CCTGAAATGTACTGCGTGGAGACGTCAGTCAGTGGCCAAAACGTCTCCACGCGC AGTACATTTC

shRNA-Foxp3

F:CACCGAGGCAGAGGACACTCAATGATTCAAGAGATCATTGAGTGTCCTCTGCCTC TTTTTTG

R: AATTCAAAAAAGAGGCAGAGGACACTCAATGATCTCTTGAATCATTGAGTGTCC TCTGCCTCG

shRNA-Foxp3-NC F: CACCGTTCTCCGAACGTGTCACGTCAAGAGATTACGTGACACGTTCGGAGAAT TTTTTG

R: AATTCAAAAAAGTTCTCCGAACGTGTCACGCTCTTGAATTACGTGACACGTTCG GAGAACG

miRNA, microRNA; shRNA, short hairpin RNA; Foxp3, forkhead family transcription factor P3; F, forward; R, reverse; NC, negative scrambled control.

at $37^{\circ} \mathrm{C}$ for $4 \mathrm{~h}$. Then, the absorbance was read at $460 \mathrm{~nm}$ using a microplate reader (Molecular Devices LLC, Sunnyvale, CA, USA). The cell survival rate was calculated as optical density (OD) test group-blank group $/ \mathrm{OD}_{\text {control group-blank group }}$.

Inhibition effect of Tregs on $C D 4^{+} C D 25^{-} T$ cells. Two healthy volunteers (one 40-year-old male weighing $75 \mathrm{~kg}$ and one 45-year-old female weighing $63 \mathrm{~kg}$ ) were recruited at The First Affiliated Hospital of Harbin Medical University in May 2014. Written informed consent was received from healthy volunteers and fasting peripheral blood samples were collected. PBMCs were separated from the peripheral blood. Tregs in the control group (90 $\mu \mathrm{l}$ medium $+10 \mu \mathrm{l}$ control plasmid) and optimal transfection group ( $\mathrm{US}+\mathrm{MB}+\mathrm{L}+\mathrm{P}$ ) were collected and co-cultured with $\mathrm{CD} 4^{+} \mathrm{CD} 25^{-} \mathrm{T}$ cells and PBMCs. CD $4^{+} \mathrm{CD} 25^{-}$ $\mathrm{T}$ cell activity was detected using the CCK8 assay according to the manufacturer's protocol. The proliferation-inhibition ratio of $\mathrm{CD}^{+} \mathrm{CD} 25^{-} \mathrm{T}$ cells was calculated as $\mathrm{OD}_{\text {cells without }}$ Tregs-cells with Tregs $/ \mathrm{OD}_{\text {cells without Tregs }}$ Supernatant was collected to detect the contents of interferon- $\gamma($ IFN- $\gamma$ ) and interleukin-2 (IL-2) secreted by $\mathrm{CD} 4^{+} \mathrm{CD} 25^{-} \mathrm{T}$ cells in addition to IL-10 and transforming growth factor- $\beta$ (TGF- $\beta$ ) secreted by Tregs using the corresponding ELISA kits (IFN- $\gamma$, E0110345; IL-2, E0110308; IL-10, E0110023; TGF- $\beta$, E01T0058; Shanghai BlueGene Biotech Co., Ltd., Shanghai, China) according to the manufacturer's protocol.

Animal model and grouping. Ethical approval was obtained from the Ethics Committee of the Animal Laboratory Center of the First Affiliated Hospital of Harbin Medical University. A total of 21 healthy male C57BL/6 mice (8 weeks old; 18-22 g) were purchased from the Animal Laboratory Center of the first affiliated hospital of Harbin medical university, and acclimatized to a $12 \mathrm{~h}$ light/dark cycle at $21^{\circ} \mathrm{C}$ with $60-70 \%$ relative humidity and given free access to food and water for a week prior to the trial. For the HCC mice model, $200 \mu 1$ Hepa1-6 cells $\left(5 \times 10^{7} / \mathrm{ml}\right.$; Shanghai Cell Bank of Chinese Academy of Sciences, Shanghai, China) were transplanted subcutaneously into the right flanks of mice in the model group $(n=18)$. The other 3 mice were treated with normal saline as a control. Following 7 days, the 18 mice in the model group were randomly and equally assigned to 2 groups $(n=9)$ : HCC and treatment groups. Mice in the treatment group were treated with microbubbles and Foxp3-shRNA plasmid, $200 \mu 1$ intravenously and $300 \mu \mathrm{l}$ directly into tumors. Mice in HCC group were injected with an equal dose of normal saline in the same method. Following injection, tumors were immediately irradiated by ultrasound for $300 \mathrm{sec}$. The treatment was repeated every 3 days, for 21 days, a total of 7 times.

Detection index. Prior to each treatment, the long diameters (a) and short diameters (b) of the tumor were detected and tumor volume was calculated as follows: $1 / 6 \pi \mathrm{a}^{2} \mathrm{~b}$. Tumor growth curves were constructed according to the tumor volume. Following 1 week of treatment, all mice were sacrificed using $1.5 \%$ pentobarbital (Sigma-Aldrich; Merck KGaA, Darmstadt, Germany) with a dose of $375 \mathrm{mg} / \mathrm{kg}$ and the tumors were weighed. The tumor inhibition rate $=$ (mean tumor weight in control group-mean tumor weight in experimental group)/mean tumor weight in control group. In addition, following treatment for 1 week, blood samples were collected. The content of $\mathrm{CD}^{+}$ and $\mathrm{CD} 25^{+} \mathrm{T}$ cells were detected by staining with CD4-FITC and CD25-Allophycocyanin conjugated antibodies (1:50; cat. nos. 553047 and 557192; BD Biosciences), respectively, using FACSCria (BD Biosciences). Briefly, the cells (1x10 ${ }^{7}$ cells $/ \mathrm{ml}$, $0.1 \mathrm{ml}$ ) were stained with CD4-FITC or CD25-Allophycocyanin conjugated antibodies for 30-40 min at room temperature in the dark. Cells were washed with PBS and samples were fixed in $1 \%$ 
formaldehyde solution at $4^{\circ} \mathrm{C}$ for $1 \mathrm{~h}$ and detected by FACSCria (BD Biosciences). Finally, the data were analyzed by FACSDiVa software (version 4.1; BD Biosciences). The content of vascular endothelial growth factor (VEGF), IL-10, TGF- $\beta$, IFN- $\gamma$ and IL-2 in serum was detected by the corresponding ELISA kits (VEGF, E03V0010; IFN- $\gamma$, E03I0345; IL-2, E03I0308; IL-10, E03I0023; TGF- $\beta$, E03T0058; Shanghai BlueGene Biotech Co. Ltd.) according to the manufacturer's protocol.

Western blot analysis. Cells and HCC tissue were collected and homogenized in pre-cooled RIPA lysis buffer. Supernatant was acquired by centrifugation at $11,347 \mathrm{x} g$ for $15 \mathrm{~min}$ at $4^{\circ} \mathrm{C}$. Subsequently; the protein concentration was detected by the BCA Protein Quantitative Assay (Sangon Shanghai Biotech Co., Ltd., Shanghai, China). A total of $40 \mu \mathrm{g}$ protein per lane sample was separated by $10 \%$ SDS-PAGE and transferred onto polyvinylidene fluoride membranes, which were blocked in $5 \%$ non-fat milk for $1 \mathrm{~h}$ at room temperature. The membranes were incubated with mouse anti-human and rabbit anti-mouse GAPDH antibodies (1:1,000; cat. nos. ab10901 and ab37168; Abcam, Cambridge, MA, USA), mouse anti-human (1:1,000; cat. no. ab10901, Abcam) and rabbit anti-mouse (1:1,000; cat. no. TA346949; Beijing Zhongshan Jingqiao Biotechnology Co., Beijing, China) Foxp3 polyclonal antibody overnight at $4^{\circ} \mathrm{C}$ and subsequently incubated with goat anti-mouse immunoglobulin $\mathrm{G}$ (IgG)-horseradish peroxidase (HRP) or goat anti-rabbit IgG-HRP (1:5,000; cat. nos. ZB-2305 and ZB-2301; Zhongshan Jingqiao Biotechnology Co.) for $2 \mathrm{~h}$ at room temperature. Ultimately, proteins were detected with enhanced chemiluminescence reagent (EMD Millipore, Billerica, MA, USA).

Statistical analysis. Statistical analysis was performed by SPSS 12.0 statistical analysis software (SPSS, Inc., Chicago, IL, USA). Data were expressed as the mean \pm standard deviation and analyzed by one-way analysis of variance followed by a least significance differences test. $\mathrm{P}<0.05$ was considered to indicate statistically significant differences.

\section{Results}

Comparison of transfection efficiency between groups. Following $24 \mathrm{~h}$ of transfection, fluorescence measurements indicated that no green fluorescent cells were present in the control group, whereas different numbers of green fluorescent cells were observed in the other six groups. $\mathrm{US}+\mathrm{MB}+\mathrm{L}+\mathrm{P}$ group had more green fluorescent cells than the other five groups (Fig. 1A). In addition, flow cytometry analysis demonstrated that transfection efficiency was $0,2.17 \pm 0.57,3.34 \pm 0.43,10.39 \pm 1.65$, $24.58 \pm 2.48,27.61 \pm 3.40$ and $46.59 \pm 4.10 \%$ in the $\mathrm{MB}+\mathrm{P}$, $\mathrm{US}+\mathrm{P}, \mathrm{US}+\mathrm{MB}+\mathrm{P}, \mathrm{L}+\mathrm{P}, \mathrm{US}+\mathrm{L}+\mathrm{P}$, and $\mathrm{US}+\mathrm{MB}+\mathrm{L}+\mathrm{P}$ groups, respectively (Fig. 1B), which were consistent with fluorescence measurements. In addition, western blot analysis demonstrated that the expression of Foxp3 was inhibited following transfection with the Foxp3-miRNA plasmid (Fig. 1B). Compared with the control group, following transfection with Foxp3-miRNA plasmid for $24 \mathrm{~h}$, the survival rate of Tregs was significantly inhibited in the other groups $(\mathrm{P}<0.01$, Table II) with the exception of the US $+\mathrm{P}$ group. All these results suggested that UTMD or Lipofectamine ${ }^{\circledR} 2000$ may effectively transfect Foxp3-miRNA into Tregs, and the combination of UTMD with Lipofectamine ${ }^{\circledR} 2000$ enhanced the transfection efficiency.

Effect of UTMD-mediated Foxp3-miRNA on the function of Tregs. The present study demonstrated that when $\mathrm{CD} 4{ }^{+} \mathrm{CD} 25$ T cells were co-cultured with PBMCs and Tregs without Foxp3-miRNA (Foxp3 ${ }^{+}$Tregs), the proliferation-inhibition ratio of $\mathrm{CD} 4^{+} \mathrm{CD} 25^{-} \mathrm{T}$ cells was significantly decreased $(\mathrm{P}<0.01$; Table III) compared with cells co-cultured with PBMCs and Tregs with Foxp3-miRNA (Foxp3 Tregs), suggesting that Foxp3 Tregs may influence the inhibition effect of Foxp $3{ }^{+}$Tregs on $\mathrm{CD}^{+} \mathrm{CD} 25^{-} \mathrm{T}$ cells proliferation.

Effect of UTMD-mediated Foxp3-miRNA on the levels of $I F N-\gamma, I L-2, I L-10$ and TGF- $\beta$ in vitro. ELISA analysis indicated that the contents of IFN- $\gamma$ and IL-2 secreted by $\mathrm{CD} 4^{+} \mathrm{CD} 25^{-} \mathrm{T}$ cells significantly increased $(\mathrm{P}<0.01)$, whereas the content of IL-10 and TGF- $\beta$ secreted by Tregs significantly decreased in the co-cultured system of Foxp3Tregs compared with the co-cultured system of Foxp $3^{+}$Tregs $(\mathrm{P}<0.01$; Table IV). These results suggested that Foxp3 3 Tregs influenced the levels of IFN- $\gamma$ and IL- 2 secreted by $C D 4^{+} \mathrm{CD} 25^{-} \mathrm{T}$ cells in addition to the level of IL-10 and TGF- $\beta$ secreted by Tregs.

Effect of UTMD-mediated Foxp3-shRNA on the tumor growth in HCC model of mice. Western blot analysis indicated that the expression of Foxp3 was reduced in the treatment group compared with the HCC group (Fig. 2A). In addition, the present study demonstrated that the mean tumor volume and tumor weight were markedly lower in the treatment group compared with the HCC group $\left(1.251 \pm 0.244\right.$ vs. $2.742 \pm 0.221 \mathrm{~cm}^{3}$ and $1.328 \pm 0.163$ vs. $3.086 \pm 0.227 \mathrm{~g} ; \mathrm{P}<0.01$; data not shown). Tumor growth curves also indicated that the average tumor volume was markedly inhibited by UTMD-mediated Foxp3-shRNA (Fig. 2B and C).

Effect of UTMD-mediated Foxp3-shRNA on Tregs and CD4 ${ }^{+}$ T cells in HCC model of mice. Flow cytometry analysis (Fig. 3) indicated that compared with the control group, the ratio of Tregs/CD4 ${ }^{+} \mathrm{T}$ cells was increased in the HCC group (4.89 \pm 0.81 vs. $3.11 \pm 0.65 \%$; $\mathrm{P}<0.05$; data not shown); however, once treated with Foxp3-shRNA, the ratio of Tregs/CD4 ${ }^{+} \mathrm{T}$ cells decreased, to below the HCC group (3.28 0.75 vs. $4.89 \pm 0.81 \%$; $\mathrm{P}<0.05$; data not shown).

Effect of UTMD-mediated Foxp3-shRNA on the levels of $I L-10, T G F-\beta, I F N-\gamma, I L-2$ and VEGF in serum of HCC mouse model. ELISA analysis demonstrated that the level of IL-10, TGF- $\beta$ and VEGF increased, whereas the levels of IFN- $\gamma$ and IL-2 decreased in HCC group, compared with the control group $(\mathrm{P}<0.05$; Table $\mathrm{V})$. However, compared with the HCC group, the level of IL-10, TGF- $\beta$ and VEGF decreased, while the level of IFN- $\gamma$ and IL-2 increased in the treatment group $(\mathrm{P}<0.05$; Table $\mathrm{V})$.

\section{Discussion}

UTMD-mediated gene therapy has been applied both in vitro and in vivo (17). In contrast with UTMD, Lipofectamine ${ }^{\circledR} 2000$ 


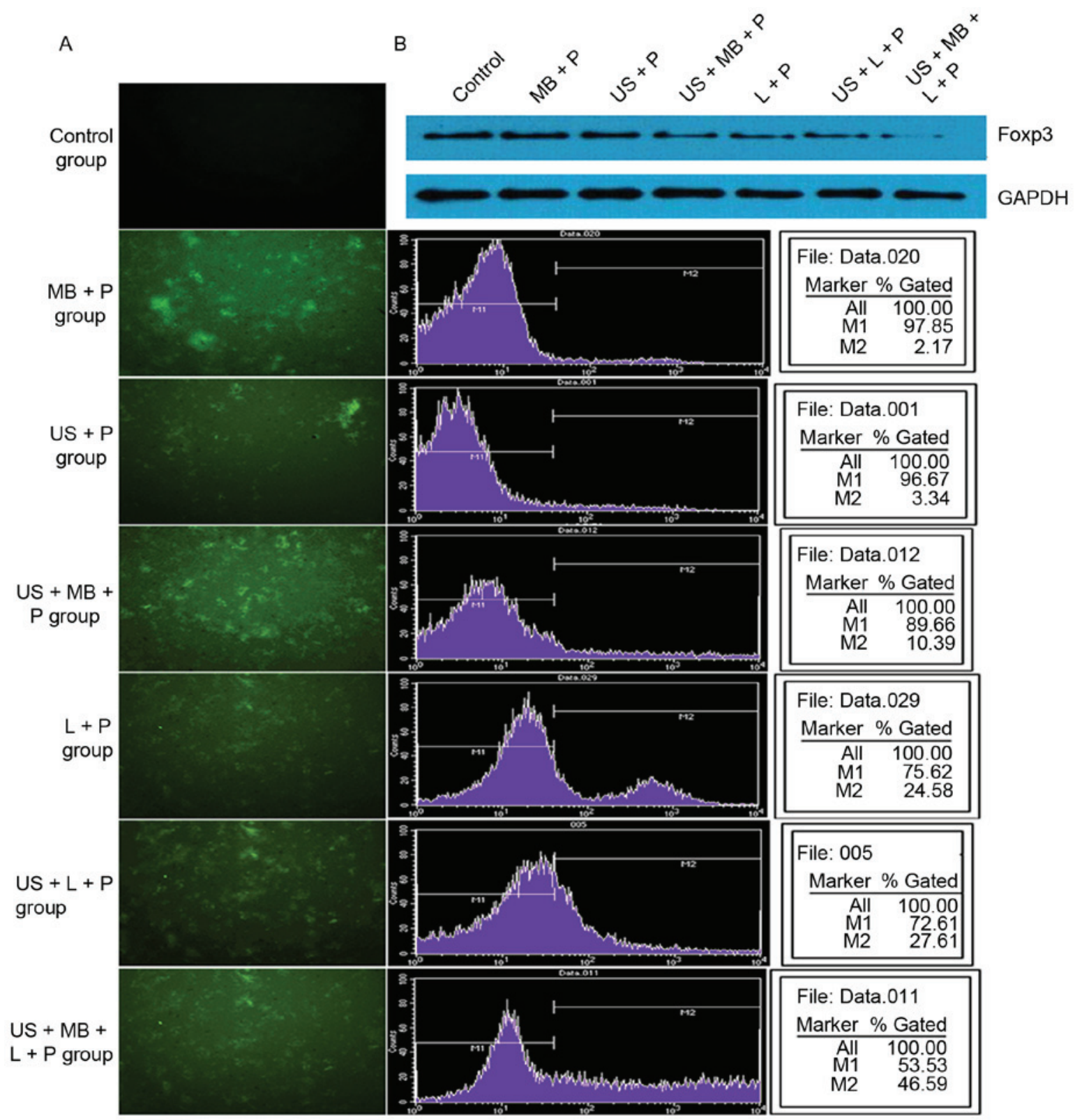

Figure 1. Transfection efficiency in different treatment groups. (A) Fluorescence measurements and flow cytometry analysis indicated that the transfection efficiency was gradually increased in the control, $\mathrm{MB}+\mathrm{P}, \mathrm{US}+\mathrm{P}, \mathrm{US}+\mathrm{MB}+\mathrm{P}, \mathrm{L}+\mathrm{P}, \mathrm{US}+\mathrm{L}+\mathrm{P}$ and $\mathrm{US}+\mathrm{MB}+\mathrm{L}+\mathrm{P}$ groups and the (B) western blot analysis demonstrated a gradual decrease in Foxp3 expression. Foxp3, forkhead family transcription factor P3; MB, SonoVue microbubbles; P, Foxp3-microRNA plasmid; US, ultrasound; L, Lipofectamine ${ }^{\circledast} 2000$.

is a common non-viral vector characterized by a low immunogenicity and high safety but low efficiency, non-targeting and increased cytotoxicity $(20,21)$. The present study demonstrated that UTMD or Lipofectamine ${ }^{\circledR} 2000$ may effectively transfect Foxp3-miRNA into Tregs, with maximum transfection efficiency observed in the US + MA + L + P group. These results suggested that the combination of UTMD with Lipofectamine ${ }^{\circledR} 2000$ may enhance transfection efficiency.

Tregs was a major factor in the suppression of the tumor-specific immune response in patients with $\mathrm{HCC}$, and the elimination or suppression of Tregs function may effectively enhance the antitumor immune response (22). Foxp3 has been demonstrated to regulate the immunosuppressive function of Tregs (23). Previous studies have indicated that the immune
Table II. Survival rate of Tregs in treatment groups.

\begin{tabular}{lc}
\hline Group & Survival rate, $\%$ \\
\hline Control & 100 \\
MB + P & $88.610 \pm 2.864^{\mathrm{a}}$ \\
US + P & $96.552 \pm 2.330$ \\
US + MB + P & $82.772 \pm 5.256^{\mathrm{a}}$ \\
L + P & $77.510 \pm 2.661^{\mathrm{a}}$ \\
US + L + P & $86.548 \pm 3.208^{\mathrm{a}}$ \\
US + MB + L + P & $80.026 \pm 1.264^{\mathrm{a}}$
\end{tabular}

${ }^{a} \mathrm{P}<0.01$ vs. control. Data are presented as mean \pm standard deviation. Treg, regulatory T cell; MB, SonoVue microbubbles; P, Foxp3-microRNA plasmid; US, ultrasound; L, Lipofectamine2000. 
Table III. Effect of Tregs with or without Foxp3-miRNA on the proliferation of $\mathrm{CD}^{+}{ }^{+} \mathrm{CD} 25^{-} \mathrm{T}$ cells.

\begin{tabular}{|c|c|c|c|c|}
\hline Index & $\begin{array}{l}\mathrm{CD}^{+} \mathrm{CD} 25^{-} \\
\mathrm{T} \text { cells group }\end{array}$ & $\begin{array}{l}\mathrm{CD}^{+} \mathrm{CD} 25^{-} \\
\mathrm{T} \text { cells }+ \\
\text { PBMCs } \\
\text { group }\end{array}$ & $\begin{array}{c}\mathrm{CD}^{+}{ }^{+} \mathrm{CD} 25^{-} \\
\text {T cells }+ \text { PBMCs }+ \\
\text { Foxp3 } 3^{+} \text {Tregs } \\
\text { group }\end{array}$ & $\begin{array}{l}\mathrm{CD}^{+}{ }^{+} \mathrm{CD} 25^{-} \\
\mathrm{T} \text { cells }+ \text { PBMCs }+ \\
\text { Foxp3 } 3^{-T r e g s} \\
\text { group }\end{array}$ \\
\hline OD value & $0.870 \pm 0.095$ & $1.544 \pm 0.138^{\mathrm{a}}$ & $0.976 \pm 0.119^{\mathrm{b}}$ & $1.254 \pm 0.114^{\mathrm{c}}$ \\
\hline Proliferation rate, $\%$ & - & $77.806 \pm 5.770$ & $12.114 \pm 3.360^{\mathrm{b}}$ & $44.606 \pm 8.974^{\mathrm{c}}$ \\
\hline Proliferation-inhibition ratio, $\%$ & - & - & $36.870 \pm 3.385$ & $18.608 \pm 5.643^{\mathrm{c}}$ \\
\hline
\end{tabular}

${ }^{\mathrm{a}} \mathrm{P}<0.01$ vs. $\mathrm{CD} 4{ }^{+} \mathrm{CD} 25$ T cells group, ${ }^{\mathrm{b}} \mathrm{P}<0.01 \mathrm{vs} . \mathrm{CD} 4{ }^{+} \mathrm{CD} 25^{-} \mathrm{T}$ cells $+\mathrm{PBMCs}$ group, ${ }^{\mathrm{c}} \mathrm{P}<0.01 \mathrm{vs}$. CD $4{ }^{+} \mathrm{CD} 25^{-} \mathrm{T}$ cells $+\mathrm{PBMCs}+\mathrm{Foxp}^{+}$Tregs group. Data are presented as mean \pm standard deviation. Treg, regulatory T cell; Foxp3, forkhead family transcription factor P3; miRNA, microRNA; CD, cluster of differentiation; Foxp3 ${ }^{+}$Tregs, Tregs without Foxp3-miRNA; Foxp3-Tregs, Tregs with Foxp3-miRNA; OD, optical density; PBMC, peripheral blood mononuclear cell.

Table IV. The effect of Tregs with or without Foxp3-miRNA on the levels of IFN- $\gamma$, IL-2, IL-10 and TGF- $\beta$.

\begin{tabular}{|c|c|c|}
\hline Index & $\begin{array}{l}\mathrm{CD}^{+}{ }^{+} \mathrm{CD} 25^{-} \\
\text {T cells }+ \text { PBMCs }+ \\
\text { Foxp3 }{ }^{+} \text {Tregs } \\
\quad \text { group }\end{array}$ & $\begin{array}{l}\mathrm{CD}^{+}{ }^{+} \mathrm{CD} 25^{-} \\
\text {T cells }+ \text { PBMCs }+ \\
\text { Foxp3-Tregs } \\
\quad \text { group }\end{array}$ \\
\hline \multicolumn{3}{|c|}{$\begin{array}{l}\mathrm{CD} 4^{+} \mathrm{CD} 25^{-} \mathrm{T} \text { cells, } \\
\mathrm{pg} / \mathrm{ml}\end{array}$} \\
\hline Level of IFN- $\gamma$ & $163.99 \pm 15.43$ & $276.38 \pm 16.83^{\mathrm{a}}$ \\
\hline Level of IL-2 & $88.57 \pm 7.57$ & $151.88 \pm 11.06^{\mathrm{a}}$ \\
\hline \multicolumn{3}{|l|}{ Tregs, pg/ml } \\
\hline Level of IL-10 & $124.25 \pm 11.33$ & $82.24 \pm 10.42^{\mathrm{a}}$ \\
\hline Level of TGF- $\beta$ & $159.93 \pm 9.19$ & $97.79 \pm 12.08^{a}$ \\
\hline \multicolumn{3}{|c|}{$\begin{array}{l}\text { aP }<0.01 \text { vs. CD } 4^{+} \mathrm{CD} 25^{-} \mathrm{T} \text { cells }+\mathrm{PBMCs}+\mathrm{Foxp} 3^{+} \text {Tregs group. Data } \\
\text { are presented as mean } \pm \text { standard deviation. Treg, regulatory T cell; } \\
\text { Foxp } 3 \text {, forkhead family transcription factor P3; miRNA, microRNA; } \\
\text { IFN- } \gamma \text {, interferon- } \gamma ; \text { IL- } 2 \text {, interleukin- } 2 \text {; TGF- } \beta \text {, transforming growth } \\
\text { factor- } \beta \text {; CD, cluster of differentiation; PBMC, peripheral blood } \\
\text { mononuclear cell. }\end{array}$} \\
\hline
\end{tabular}

responses induced by $\mathrm{CD} 4^{+} \mathrm{CD} 25^{-} \mathrm{T}$ cells may be inhibited by $\mathrm{CD} 4{ }^{+} \mathrm{CD} 25^{+}$Tregs in vitro through cytokine-independent mechanisms $(24,25)$. Liyanage et al (26) demonstrated that Tregs from patients with pancreas or breast adenocarcinoma secreted IL-10 and TGF- $\beta$; however, when Tregs were co-cultured with $\mathrm{CD}^{+} 25^{-} \mathrm{T}$ cells, Tregs were able to inhibit the proliferation in addition to the secretion of IFN- $\gamma$ and IL-2 in $\mathrm{CD}^{+}{ }^{+25^{-}} \mathrm{T}$ cells. Furthermore, Foxp3 is able to suppress the production of IFN- $\gamma$ and IL-2 secreted by effector T cells, while upregulating the level of IL-10 and TGF- $\beta$ secreted by Tregs (27). Furthermore, Foxp $3^{+}$Tregs is able to suppress the activation of $\mathrm{T}$ cells and inhibit the proliferation of effector $\mathrm{CD}^{+} \mathrm{T}$ cells (28). Notably, Foxp3 knockdown may enhance tumor immunity (29). Consistently, the current study demonstrated that Foxp3-Tregs reduced the inhibition effect of Foxp $3^{+}$Tregs from patients with $\mathrm{HCC}$ on the proliferation of $\mathrm{CD}^{+} \mathrm{CD}^{+} 5^{-} \mathrm{T}$ cells. In addition, Foxp3 Tregs may also
Table V. Effect of Foxp3 knockdown on the level of IL-10, TGF- $\beta$, IFN- $\gamma$, IL-2 and VEGF in serum in vivo.

\begin{tabular}{lccc}
\hline Factor, pg/ml & $\begin{array}{c}\text { Control } \\
\text { group } \\
(\mathrm{n}=3)\end{array}$ & $\begin{array}{c}\text { HCC } \\
\text { group } \\
(\mathrm{n}=9)\end{array}$ & $\begin{array}{c}\text { Treatment } \\
\text { group } \\
(\mathrm{n}=9)\end{array}$ \\
\hline IL-10 & $111.09 \pm 6.19$ & $132.99 \pm 7.15^{\mathrm{b}}$ & $102.39 \pm 4.82^{\mathrm{d}}$ \\
TGF- $\beta$ & $124.06 \pm 8.12$ & $159.68 \pm 7.88^{\mathrm{b}}$ & $124.26 \pm 5.99^{\mathrm{d}}$ \\
IFN- $\gamma$ & $46.18 \pm 8.85$ & $21.78 \pm 3.56^{\mathrm{a}}$ & $45.25 \pm 10.36^{\mathrm{c}}$ \\
IL-2 & $61.25 \pm 6.62$ & $37.88 \pm 4.88^{\mathrm{b}}$ & $59.09 \pm 4.96^{\mathrm{d}}$ \\
VEGF & $48.88 \pm 8.11$ & $68.35 \pm 4.69^{\mathrm{a}}$ & $44.11 \pm 5.79^{\mathrm{d}}$ \\
\hline
\end{tabular}

${ }^{\mathrm{a}} \mathrm{P}<0.05,{ }^{\mathrm{b}} \mathrm{P}<0.01$ vs. control, ${ }^{\mathrm{c}} \mathrm{P}<0.05,{ }^{\mathrm{d}} \mathrm{P}<0.01$ vs. HCC group. Data are presented as the mean \pm standard deviation. Foxp3, forkhead family transcription factor P3; IL, interleukin; TGF- $\beta$, transforming growth factor- $\beta$; IFN- $\gamma$, interferon- $\gamma$; VEGF, vascular endothelial growth factor; HCC, hepatocellular carcinoma.

increase the level of IFN- $\gamma$ and IL- 2 secreted by CD $4{ }^{+} \mathrm{CD} 25$ T cells but decrease the level of IL-10 and TGF- $\beta$ secreted by Tregs. These results indicate that the downregulation of Foxp3 may mitigate the immunosuppressive function of Tregs.

It has been suggested that the immunosuppressive function of Tregs, at least partially, contributed to the proliferation of tumor cells (30). A previous study indicated that a depletion of Tregs may enhance tumor immunity and inhibit tumor growth in patients with HCC (12). Notably, the present study revealed that UTMD-mediated Foxp3-shRNA inhibited the tumor growth in HCC model mice, suggesting that UTMD-mediated Foxp3-shRNA may inhibit the function of Tregs. In addition, the current study also indicates that the downregulation of Foxp3 reduced the ratio of Tregs/CD4 ${ }^{+} \mathrm{T}$ cells. Following treatment with Foxp3-shRNA, the level of IL-10 and TGF- $\beta$ decreased, while the level of IFN- $\gamma$ and IL-2 increased, in the current study. These results indicate that the downregulation of Foxp3 enhanced the immunologic function and anti-tumor effect. Furthermore, the present study also demonstrated that UTMD-mediated Foxp3-shRNA reduced the level of VEGF. It has been demonstrated that VEGF promotes the 
A

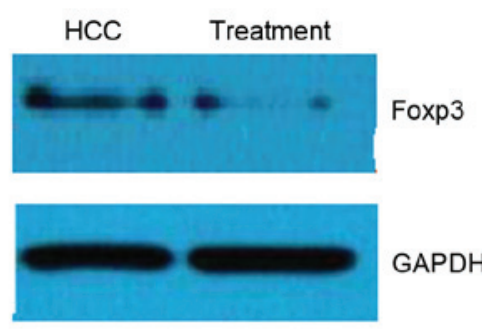

B

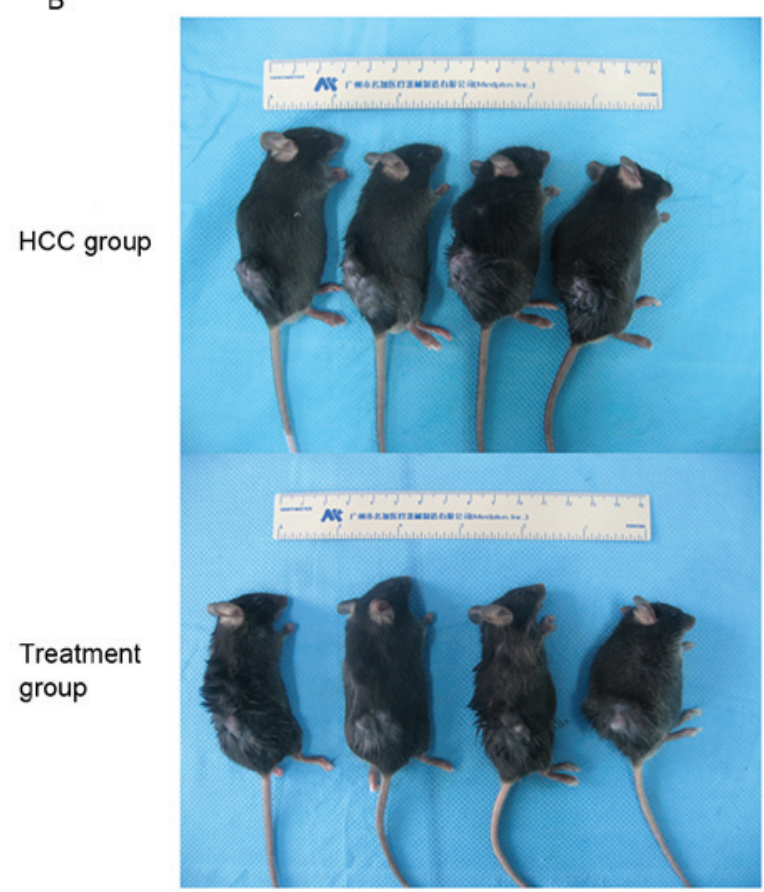

C

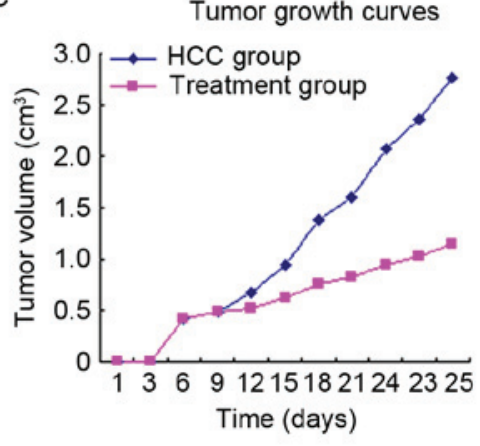

Figure 2. Effect of Foxp3 knockdown on the HCC model of mice. Following treatment with Foxp3-short hairpin RNA, (A) western blot analysis indicated a reduced expression of Foxp3; (B) tumor volume was reduced and (C) tumor growth curves demonstrated a trend of decreased tumor volume compared with the HCC group. Foxp3, forkhead family transcription factor P3; HCC, hepatocellular carcinoma.

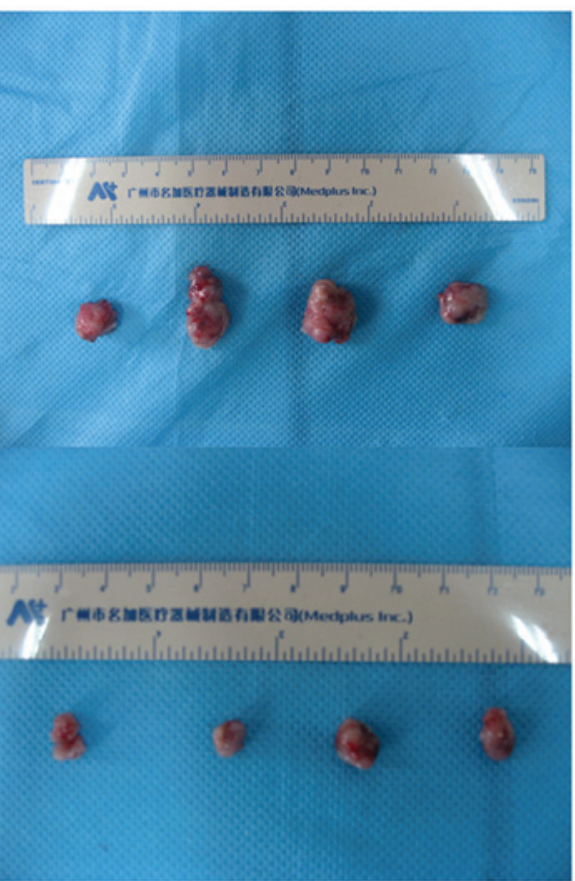

\begin{tabular}{cr}
\multicolumn{2}{c}{ Control group } \\
Quad & $\%$ Gated \\
\hline UL & 8.90 \\
UR & 3.50 \\
LL & 62.74 \\
LR & 24.85
\end{tabular}

\begin{tabular}{cr}
\multicolumn{2}{c}{ HCC group } \\
Quad & $\%$ Gated \\
\hline UL & 6.11 \\
UR & 4.63 \\
LL & 60.37 \\
LR & 28.88
\end{tabular}
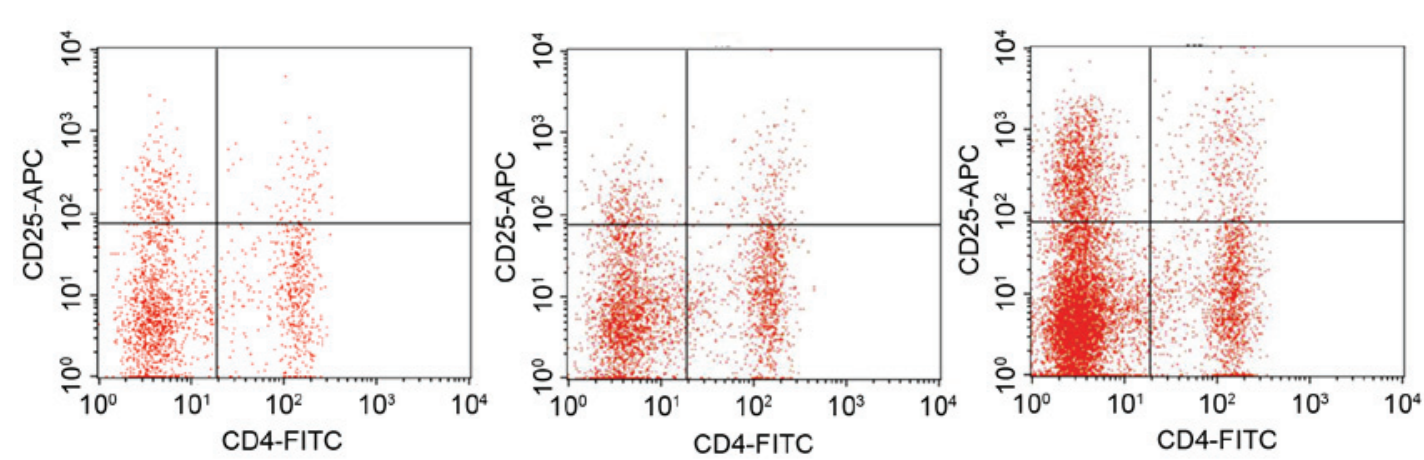

Figure 3. Content of regulatory $\mathrm{T}$ cells and $\mathrm{CD} 4^{+} \mathrm{T}$ cells in the blood of mice, by flow cytometry analysis for the control, $\mathrm{HCC}$ and treatment group. $\mathrm{CD}$, cluster of differentiation; HCC, hepatocellular carcinoma; FITC, fluorescein isothiocyanate; APC, allophycocyanin; UL, upper left; UR, upper right; LL, lower left; LR, lower right. 
formation of tumor angiogenesis and inhibits the apoptosis of tumor cells (31). These results indicate that UTMD-mediated Foxp3-shRNA may partially inhibit the tumor growth in HCC mice through suppressing the production of VEGF.

Inconclusion, the current study demonstrated that the combination of UTMD with Lipofectamine ${ }^{\circledR} 2000$ may be the optimal choice to enhance the transfection efficiency in gene therapy. Furthermore, UTMD-mediated Foxp3-miRNA/shRNA may relieve the immunosuppressive function of Tregs in patients with HCC in vitro, and partially inhibit the tumor growth in HCC mice through enhancing immunologic function and suppressing the production of VEGF. The present study is not without limitations; the long-term effects of UTMD-mediated Foxp3-miRNA/shRNA on immunologic function and tumor growth remain unclear. Therefore, the safety and efficacy of UTMD-mediated Foxp3-miRNA/shRNA should be further investigated in the future.

\section{Acknowledgements}

The present study was supported by General Projects of National Natural Science Foundation of China (grant no. 81171346), the Research Foundation Of The Talent Of Scientific And Technical Innovation of Harbin City (grant no. 2016RAQXJ148), General Projects of Heilongjiang Province Natural Science Foundation of China (grant no. H2017026) and the Scientific Research Innovation Fund of The First Affiliated Hospital of Harbin Medical University.

\section{References}

1. Han KH, Kudo M, Ye SL, Choi JY, Poon RP, Seong J, Park JW, Ichida T, Chung JW, Chow P and Cheng AL: Asian consensus workshop report: Expert consensus guideline for the management of intermediate and advanced hepatocellular carcinoma in Asia. Oncology 81 (Suppl 1): S158-S164, 2011.

2. Jemal A, Bray F, Center MM, Ferlay J, Ward E and Forman D: Global cancer statistics. CA Cancer J Clin 61: 69-90, 2011.

3. Maluccio M and Covey A: Recent progress in understanding, diagnosing, and treating hepatocellular carcinoma. CA Cancer J Clin 62: 394-399, 2012.

4. Pardee AD and Butterfield LH: Immunotherapy of hepatocellular carcinoma: Unique challenges and clinical opportunities Oncoimmunology 1: 48-55, 2012.

5. Ganss R and Hanahan D: Tumor microenvironment can restrict the effectiveness of activated antitumor lymphocytes. Cancer Res 58: 4673-4681, 1998.

6. Coussens LM and Werb Z: Inflammation and cancer. Nature 420: $860-867,2002$

7. Linehan DC and Goedegebuure PS: CD25+CD4+ regulatory T-cells in cancer. Immunol Res 32: 155-168, 2005.

8. von Boehmer H: Mechanisms of suppression by suppressor $\mathrm{T}$ cells. Nat Immunol 6: 338-344, 2005.

9. Fontenot JD and Rudensky AY: A well adapted regulatory contrivance: Rregulatory T cell development and the forkhead family transcription factor Foxp3. Nat Immunol 6: 331-337, 2005.

10. Tsai BY, Suen JL and Chiang BL: Lentiviral-mediated Foxp3 RNAi suppresses tumor growth of regulatory $\mathrm{T}$ cell-like leukemia in a murine tumor model. Gene Ther 17: 972-979, 2010.

11. Ormandy LA, Hillemann T, Wedemeyer H, Manns MP, Greten TF and Korangy F: Increased populations of regulatory $\mathrm{T}$ cells in peripheral blood of patients with hepatocellular carcinoma. Cancer Res 65: 2457-2464, 2005.

12. Yang XH, Yamagiwa S, Ichida T, Matsuda Y, Sugahara S, Watanabe H, Sato Y, Abo T, Horwitz DA and Aoyagi Y: Increase of CD4+CD25+ regulatory T-cells in the liver of patients with hepatocellular carcinoma. J Hepatol 45: 254-262, 2006.
13. Walton CB, Anderson CD, Boulay R and Shohet RV: Introduction to the ultrasound targeted microbubble destruction technique. J Vis Exp 52: e2963, 2011.

14. Geis NA, Katus HA and Bekeredjian R: Microbubbles as a vehicle for gene and drug delivery: Current clinical implications and future perspectives. Curr Pharm Design 18: 2166-2183, 2012.

15. Li YS, Davidson E, Reid CN and McHale AP: Optimising ultrasound-mediated gene transfer (sonoporation) in vitro and prolonged expression of a transgene in vivo: Potential applications for gene therapy of cancer. Cancer Lett 273: 62-69, 2009.

16. Fujii H, Sun Z, Li SH, Wu J, Fazel S, Weisel RD, Rakowski H, Lindner J and Li RK: Ultrasound-targeted gene delivery induces angiogenesis after a myocardial infarction in mice. JACC Cardiovasc Imaging 2: 869-879, 2009.

17. Carson AR, McTiernan CF, Lavery L, Hodnick A, Grata M, Leng X, Wang J, Chen X, Modzelewski RA and Villanueva FS: Gene therapy of carcinoma using ultrasound-targeted microbubble destruction. Ultrasound Med Biol 37: 393-402, 2011.

18. Kee KM, Wang JH, Lin CY, Wang CC, Cheng YF and Lu SN: Validation of the 7th edition TNM staging system for hepatocellular carcinoma: An analysis of 8,828 patients in a single medical center. Dig Dis Sci 58: 2721-2728, 2013.

19. Saayman SM, Lazar DC, Scott TA, Hart JR, Takahashi M, Burnett JC, Planelles V, Morris KV and Weinberg MS: Potent and targeted activation of latent HIV-1 using the CRISPR/dCas9 activator complex. Mol Ther 24: 488-498, 2016.

20. Ewert KK, Ahmad A, Bouxsein NF, Evans HM and Safinya CR: Non-viral gene delivery with cationic liposome-DNA complexes. In: Gene Therapy Protocols. Springer, New York, NY, pp159-175, 2008.

21. Karmali PP and Chaudhuri A: Cationic liposomes as non-viral carriers of gene medicines: Resolved issues, open questions, and future promises. Med Res Rev 27: 696-722, 2007.

22. Zhang HH, Mei MH, Fei R, Liao WJ, Wang XY, Qin LL, Wang JH, Wei L and Chen HS: Regulatory T cell depletion enhances tumor specific CD8 T-cell responses, elicited by tumor antigen NY-ESO-1b in hepatocellular carcinoma patients, in vitro. Int J Oncol 36: 841-848, 2010.

23. Fontenot JD, Rasmussen JP, Williams LM, Dooley JL, Farr AG and Rudensky AY: Regulatory T cell lineage specification by the forkhead transcription factor foxp3. Immunity 22: 329-341, 2005.

24. Dieckmann D, Plottner H, Berchtold S, Berger T and Schuler G: Ex vivo isolation and characterization of CD4(+) CD25(+) T cells with regulatory properties from human blood. J Exp Med 193: 1303-1310, 2001.

25. Shevach EM: CD4+ CD25+ suppressor T cells: More questions than answers. Nature Rev Immunol 2: 389-400, 2002.

26. Liyanage UK, Moore TT, Joo HG, Tanaka Y, Herrmann V, Doherty G, Drebin JA, Strasberg SM, Eberlein TJ, Goedegebuure PS and Linehan DC: Prevalence of regulatory $\mathrm{T}$ cells is increased in peripheral blood and tumor microenvironment of patients with pancreas or breast adenocarcinoma. J Immunol 169: 2756-2761,2002.

27. Ono M, Yaguchi H, Ohkura N, Kitabayashi I, Nagamura Y, Nomura T, Miyachi Y, Tsukada T and Sakaguchi S: Foxp3 controls regulatory T-cell function by interacting with AML1/Runx1. Nature 446: 685-689, 2007.

28. Pandiyan $\mathrm{P}$, Zheng L, Ishihara $\mathrm{S}$, Reed $\mathrm{J}$ and Lenardo $\mathrm{MJ}$ : $\mathrm{CD} 4+\mathrm{CD} 25+$ Foxp3+ regulatory $\mathrm{T}$ cells induce cytokine deprivation-mediated apoptosis of effector CD4+ T cells. Nat Immunol 8: 1353-1362, 2007.

29. Nair S, Boczkowski D, Fassnacht M, Pisetsky D and Gilboa E: Vaccination against the forkhead family transcription factor Foxp3 enhances tumor immunity. Cancer Res 67: 371-380, 2007.

30. Nishikawa $\mathrm{H}$ and Sakaguchi S: Regulatory $\mathrm{T}$ cells in tumor immunity. Int J Cancer 127: 759-767, 2010.

31. Kim KJ, Li B, Winer J, Armanini M, Gillett N, Phillips HS and Ferrara N: Inhibition of vascular endothelial growth factor-induced angiogenesis suppresses tumour growth in vivo. Nature 362: 841-844, 1993

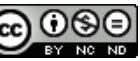

This work is licensed under a Creative Commons Attribution-NonCommercial-NoDerivatives 4.0 International (CC BY-NC-ND 4.0) License. 